\title{
BETWEEN ICMI AND NU: The Contested Representation of Muslim Civil Society in Indonesia, 1990-2001
}

\author{
Arskal Salim
}

Aga Khan University, London, United Kingdom

\begin{abstract}
:
This article discusses the concept of Muslim civil society in Indonesia by looking at differences in context between democratic and non-democratic regimes and by considering the diversity of Islamic interpretation of civil society and democracy. By looking at the dynamics within state-society relations and the process of democratisation, this article aims to clarify what kind of political actions correspond to the concept of civil society and help build a strong civil society in Indonesia in 1990s. Limiting its scope to the period from 1990 to 2001, the paper draws on two Muslim organisations Nabdlatul Ulama and Ikatan Cendekiawan Muslim Indonesia) to explain why do Indonesian Muslims use the concept of civil society differently? How should Muslims perceive civil society vis-à-vis the state? Is it cooperation (participation) or opposition? Are both respective views equally legitimate? Given that Islamic doctrine may support the most varied of political outlooks, this study will point out that there is no single interpretation of the relationship between Islam and civil society or democracy. The article thus argues that differences between the two groups represent the diversity of Islamic interpretations of socio-political life.
\end{abstract}

[Artikel ini membahas konsep "civil society" di Indonesia berdasarkan perbedaan konteks antara rejim demokratis dan otoriter serta menganalisis ragam interpretasi Islam mengenai civil society dan demokrasi. Melalui analisis dinamika bubungan rakyat-negara dan proses demokratisasi, artikel ini menjelaskan bentuk sikap politik yang sesuai dengan civil society 
dan mendorong terciptanya civil society yang kuat pada dekade 1990 an di Indonesia. Diskusi dibatasi pada dua organisasi Muslim di Indonesia, Nabdlatul Ulama (NU) dan Ikatan Cendekiawan Muslim Indonesia (ICMI), dan hanya pada rentang 1990 bingga 2001. Pembatasan dilakukan guna menjawab mengapa Muslim di Indonesia menggunakan konsep civil society secara berbeda dan bagaimana mereka memandang bentuk relasi ideal antara negara-civil society; apakah kerjasama (partisipasi) ataukah oposisi? dan apakah kedua bentuk relasi tersebut sama-sama dapat dibenarkan?. Menyimak babwa ajaran Islam dapat digunakan untuk mendukung berbagai pandangan politik, artikel ini menggarisbawahi bahwa interpretasi mengenai relasi Islam dan civil society/demokrasi adalah beragam. Karena itu, perbedaan antara NU dan ICMI dalam menterjemabkan konsep civil society merupakan cerminan perbedaan dan ragam interpretasi Islam terhadap kebidupan sosial-politik.]

Keywords: civil society, masyarakat madani, masyarakat sipil, opposition, participation

\section{A. Introduction}

Civil society is a concept that has been much discussed in both the West and many Muslim countries. Its Arabic equivalent is mijtama' madaniy. This is the expression used to convey the idea of civil society in Middle Eastern countries. In Indonesia, the most populous Muslim country in the world, it is a concept that is more often cited than understood. It seems that there is no agreement on what civil society implies. It is believed, on the one hand, that civil society needs state support for its survival. On the other hand, it is thought that civil society will survive if it can avoid being co-opted by the state. In addition, some studies on Muslim civil society in Indonesia however in general lack two things: ${ }^{1}$ (1)

${ }^{1}$ Robert W. Hefner has written two articles on this subject, "Islam, State, and Civil Society: ICMI and The Struggle for the Indonesian Middle Class," Indonesia 56 (October 1993). This article was republished in Robert W. Hefner and Patricia Horvatich (eds.), Politics and Religious Renewal in Muslim Southeast Asia (Honolulu: University of Hawai'i Press, 1997) as "Islamization and Democratization in Indonesia." For citation, this paper will refer to the latter; "A Muslim Civil Society? Indonesian Reflections on the conditions of its possibility," in Robert W. Hefner (ed.), Democratic Civility: The History and Cross-Cultural Possibility of a Modern Political Ideal (New Brunswick and London; 
they overlook the differences in context between democratic and nondemocratic regimes; and (2) none of these studies is concerned with the diversity of Islamic interpretation of civil society and democracy. This study seeks to fill these gaps.

There are basically three problematic features in Indonesian Muslim civil society. Firstly, during the last decade of the New Order rule, the concept of civil society was termed differently by Islamic groups in Indonesia. One group translates it as masyarakat madani in Bahasa Indonesia. This originated from Malaysia and was introduced to Indonesia in 1994 by Anwar Ibrahim, the ex-deputy Prime Minister of Malaysia. The other group considers the use of masyarakat madani implied political co-opting, since it has been contaminated with the authoritarian regime interest. Although masyarakat sipil is sometimes used, they prefer the English "civil society" to masyarakat madani. Secondly, there is a difference in connotations as well. Those who use masyarakat madani seem to identify civil society with the emergence of the Indonesian Muslim middle class, particularly referring to Ikatan Cendekiawan Muslim Indonesia/ICMI. ${ }^{2}$ Others who use "civil society" link the term to Nahdatul Ulama/NU, the mass organisation formerly headed by Abdurrahman Wahid. Sometimes

Transaction Publishers, 1998); Muhammad AS. Hikam, "Islam and the Empowerment of Indonesian Civil Society," The Indonesian Quarterly, vol. 24 (1), 1996; "Khittah dan Penguatan Civil Society di Indonesia: Sebuah Kajian Historis Struktural atas NU sejak 1984," in Ellyasa KH. Dharwis, Gus Dur, NU, dan Masyarakat Sipil (Yogyakarta: LKiS, 1994); Dawam Rahardjo, "ICMI, Masyarakat Madani, dan Masa Depan Politik Indonesia: Sebuah Catatan Akhir," An Interview in Nasrullah Ali-Fauzi (ed.), ICMI: Antara Status Quo dan Demokratisasi (Bandung: Mizan, 1995); Muslim Abdurrahman, "Muslim Civil Society di Indonesia: Siapakah yang Memerankannya di Masa Depan?," in Muslim Abdurrahman, Semarak Islam, Semarak Demokrasi (Jakarta: Pustaka Hidayah, 1996); Ahmad Baso, Civil Society versus Masyarakat Madani: Arkeologi Pemikiran Civil Society dalam Islam Indonesia (Jakarta: Pustaka Hidayah, 1999).

${ }^{2}$ ICMI is the Association of Indonesian Muslim Intellectuals, which headed by BJ. Habibie, the Minister of Research and Technology and then president of Indonesia (1998-1999). It was founded in 1990 with President Soeharto's sponsorship. See Dawam Rahardjo, "Visi dan Misi Kehadiran ICMI: Sebuah Pengantar," in Nasrullah Ali-Fauzi (ed.), ICMI: Antara Status Quo dan Demokratisasi..

${ }^{3} \mathrm{NU}$ is the organisation of Islamic traditional scholars based mostly in rural Java. It was founded in 1926, long before Indonesian independence (1945). Abdurrahman Wahid, the former president of Indonesia, was the chairman of this organisation for three terms (1984-1999). 
they also refer to Wahid's own manoeuvres. ${ }^{4}$ Given this, there were two Islamic groups contesting to be truly representatives or agents of civil society in Indonesia. Finally, one group that uses masyarakat madani defines civil society as more than the pro-democracy movements that challenge the power of the authoritarian regime. Since civil society also refers to the structuring of civility and civilised society, this group (ICMI) considers the contribution of, and a cooperation with, the state is necessary. It is no wonder that in the days of the Habibie administration (1998-1999), a state council was established with the main task of which was to develop civil society. Meanwhile, the other group (NU) tends to indicate civil society as an avenue for democratisation. Thus, it is understood as a concept that emphasises autonomy from the state. So, "civil society" should be dissociated from state political cooptation.

Focusing on Islam and civil society in an Indonesian context and limited to the years 1990-2001, this article will explain why do Indonesian Muslims use the concept of civil society differently? What is the nature of these differences and their causes? Which of groups best represents civil society? Are their respective views equally legitimate? How should Muslims perceive civil society vis-à-vis the state? Is it cooperation (participation) or opposition? In term of civil society empowerment, are there differences between democratic and authoritarian regimes? Instead of observing civil society by identifying its forms or characteristics, this study will identify its performance by looking at the dynamics within state-society relations and the process of democratisation, particularly in the 1990s. This article aims to clarify what kind of political actions correspond to the concept of civil society and help build civil society in Indonesia.

What are the parameters of the success of civil society? This paper identifies civil society by referring to a dual dynamic -that is, to resist subordination to the state and to demand inclusion into national political structure. ${ }^{5}$ Given this dual dynamic of civil society, it is as successful as the citizenship rights acquired by the people. Here, I will use theory of

${ }^{4}$ Muhammad AS. Hikam, "Khittah dan Penguatan Civil Society di Indonesia: Sebuah Kajian Historis Struktural atas NU sejak 1984."

${ }^{5}$ Philip Oxhorn, "From Controlled Inclusion to Reactionary Exclusion: The Struggle for Civil Society in Latin America," in John Hall (ed.), Civil Society: Theory, History and Comparison (Cambridge: Polity Press, 1995). 
citizenship put forward by Marshall as the general parameters of the success of civil society. ${ }^{6}$ Basically, civil rights, political rights and social rights are weak, if not lacking altogether, in non-democratic regimes. Therefore, civil society may demand all these rights. Thus, it might be noted here that the success of civil society depends on its ability to reject the state interventions and the extent to which the state responds to the demands of civil society. Nonetheless, one could argue that the protests over the lack of citizenship rights or the anti-democratic policies represent a symbolic success of civil society. However, even then the success ultimately would still depend on getting the regime to respond to specific demands of citizenship rights.?

In the following section, I will briefly establish the framework and give a theoretical overview of the literature on civil society-state relations. Given that Islamic doctrine may support the most varied of political outlooks, this study will point out that there is no single interpretation of the relationship between Islam and democracy. Accordingly, I will argue that differences between the two groups represent the diversity of Islamic interpretations of socio-political life, including civil society and democracy. Thus, I will reject the predominant view among Western observers, for instance as advocated by Huntington, which characterise Islam as a monolith. ${ }^{8}$

The next section afterwards will focus on the discourses on civil society and its development in Indonesia. The discussion will not only be on the theoretical debates but, more importantly, the dynamics of the

${ }^{6}$ According to Marshall, citizenship has three parts: civil, political and social. The civil element is composed of the rights necessary for individual freedom-liberty of person, freedom of speech, thought and faith. The political element is associated with the right to participate in the exercise of political power. The social element includes the entire range: from the right to a modicum of economic welfare and security to the right to share fully in the social heritage and to live the life of a civilised being according to the standards prevailing in the society. T.H., Marshall, Citizenship and Social Class and Other Essays (Cambridge: Cambridge University Press, 1950).

${ }^{7}$ Philip Oxhorn, Organizing Civil Society: The Popular Sectors and the Struggle for Democracy in Chile (University Park: The Pennsylvania State University Press, 1995).

${ }^{8}$ See for instance, Samuel P. Huntington, "The Clash of Civilizations," Foreign Affairs, 72: 3, 1993, pp. 22-50. 
struggle of rights in Indonesia. ${ }^{9}$ In this section, I will compare the sociopolitical actions of the ICMI and the NU, particularly their commitments to building civil society. Finally, the last part of this study will discuss the situation of Muslim civil society during the presidency of Abdurrahman Wahid (1999-2001). Now that civil rights and political rights became widely recognised, the social rights in turn would be paid more attention. In such a situation, the success of civil society to deal with the problem of social rights would determine the pathway to a sustainable democracy.

\section{B. Civil Society against the State? A Theoretical Overview}

Perhaps the best description of the origin of civil society is found in John Keane's. He points out that the idea of civil society has a long pedigree. ${ }^{10}$ The term is inherited from antiquity since Cicero introduced societas civilis. This term initially was interchangeable with the state but, since its reappearance in the eighteenth century England and Western Europe, it became distinguishable from the state.

Keane mentions four phases of the development of civil society since that time. The first phase is the subject of An Essay on the History of Civil Society (1767) by Adam Ferguson. In his work, Ferguson associates civil society with the concept of state. Civil society was "a type of political order which protects and polishes its mechanical and commercial arts, as well as its cultural achievements and sense of public spirit, by means of regular government, the rule of law and strong military defenses." Obviously, Ferguson expressed civil society as the antithesis of primitive society rather than the antithesis of political society. ${ }^{11}$

Thomas Paine's polemical (1791-2) Rights of Man signalled the second phase in the development of civil society. He contrasted civil

${ }^{9}$ This approach is lacking in Baso's work. His work focuses mainly on the theoretical debates over the concept of civil society. Generally, Baso's work is a critical study based on Foucault's method. Approaching the problem with an archaeology of thought and since it focuses basically on textual analysis, not the empirical observations, the study's conclusion seemed either pessimistic or sceptical about the potential emergence of Muslim civil society in Indonesia.

${ }^{10}$ John Keane, "Despotism and Democracy: The Origins and Development of the Distinction Between Civil Society and the State 1750-1850," in John Keane (ed.), Civil Society and The State: New European Perspectives (New York: Verso, 1988).

${ }^{11}$ Ibid. 
society with the state. According to Paine, "[T] he power of the state must be restricted in favor of civil society... The state is deemed a necessary evil... The legitimate state is nothing more than a delegation of power for the common benefit of society. The more perfect civil society, the more it regulates its own affairs and the less occasion it has for government."

Attracted by his predecessor's account on civil society, George W.F. Hegel proposed in Grundlinen der Philosophie des Rechts (1821) the third phase of development of civil society. Contrasted to Paine's concept, civil society was viewed as "a self-crippling entity in constant need of state supervision and control. Civil society cannot remain 'civil' unless it is ordered politically, subjected to the higher surveillance of the state. Only a supreme public authority can effectively remedy its injustices and synthesise its particular interests into a universal political community." Seen from this perspective, civil society was perceived as very weak, indeed incapable of standing on its own and should therefore ask the state to overcome its own problems. For Hegel, state intervention was legitimate. He offered two conditions under which the state may intervene in the affairs of civil society. The first was to remedy injustices or inequalities in civil society. The second was to protect and further the universal interest of the population, which the state itself defines. These two conditions, Keane held, constitute a very broad license for state regulation and dominance of social life. Although Hegel differentiated civil society from the state, he subordinated the former to the latter.

The fourth phase of the theoretical development of civil society is the theme of Alexis De Tocqueville's work De la democratie en Amerique (1835-1840). In reaction to Hegel, Tocqueville held that arguments in defense of a state that governs civil society in the name of the universal interest imply a dangerous development: the growth of a new type of state despotism. Concerned with the rising new despotism that threatened democratic revolution, Tocqueville warned of arbitrary state regulation, which can result in the weakening of civil society. As Keane stated, "The more state institutions become practically involved in the provision of 'public utilities', the less civil society can cope without state direction." 12 Furthermore, Tocqueville suggested that the only way to preserve the equality and freedom of all citizens is by preventing the state from abusing

${ }^{12}$ Ibid. 
its powers and robbing its citizens of their freedom. He believes that "a pluralistic and self-organizing civil society independent of the state is an indispensable condition of democracy." Through civil associations, citizens can negotiate with the polity. Civil associations are "arenas in which individuals can direct their attention to more than their selfish, conflictual, narrowly private goals. Through their activities in such arenas, they come to perceive that they are not independent of their fellowcitizens and that in order to obtain others' support they must often lend them their cooperation."

Nonetheless, the abolishment of political institution (the state) is not the solution, since active and strong institutions are both necessary and desirable conditions. So, although Tocqueville acknowledges that civil associations always depend on centralised state institutions for their survival and coordination, his position differed from that of Hegel. He held that the freedom and equality of individuals and groups depended on the preservation of organisations which nurture local freedoms and provide for the active expression of particular interests.

What is important to recognise here is that all concepts of civil society mentioned above essentially reflected the realities faced by its theorists. Ferguson was worried about the paralysing dangers of civil societies to establishing regular government and promoting commerce and manufacturing. Paine was disappointed that most states crush and oppress their populations. Both Hegel's and Tocqueville's were reactions to their predecessors' concepts of civil society. Seen from this perspective, it is objectionable to describe existing civil society in certain contexts without looking at how and where (under what kind of governance system) it emerges.

Basically, the relationship between the state and civil society has not historically taken one form. The arguments above show that civil society had been defined in terms of its interaction -more precisely antagonismwith the state. Since Paine, some scholars tended to juxtapose civil society with the state, not contrasting them. Antonio Gramsci's work is typical of this. ${ }^{13}$ Gramsci defined civil society as "the political and cultural hegemony that a social group exercises over the whole of society, as the

${ }^{13}$ Norberto Bobbio, "Gramsci and the Concept of Civil Society", in John Keane, (ed.), Civil Society and The State: New European Perspectives (New York: Verso, 1988). 
ethical content of the state." He identified two major superstructural levels: the one than can be called civil society, that is the ensemble of organisms commonly called private, and that of political society or the state. These two levels correspond, on the one hand, to the function of hegemony which the dominant group exercises throughout society, and on the other hand, to that of direct domination or rule exercised through the state and the juridical government."

According to Bobbio, Gramsci was indebted to Hegel for his concept of civil society, although via a rather biased interpretation of his thought. ${ }^{14}$ In fact, Gramsci seems more optimistic than Hegel about the self-sufficiency of civil society. In his view, civil society plays a major role in the withering away of the state. Put in Gramscian ideality, the end of the state is conceived as "a reabsorption of political society in civil society" or "civil society without political society." From this perspective, despite the multiple dimensions, one may plausibly emphasise that the main characteristic of civil society is its opposition to the state. There is always a contest between the state and civil society. Such contest is more evident in non-democratic regimes than democratic ones. ${ }^{15}$

However, it is important to consider here what Charles Taylor (1990) once pointed out that transposing too easily the result of the historical development of civil society specific to Western Europe to other countries that do not necessarily share the same preconditions is dangerous. According to Chatterjee, Taylor seems to consider the statecivil society opposition is oversimplification even in the case of Western liberal democracies. ${ }^{16}$ In the light of this Taylor's criticism, this study will ponder different kinds of Muslim civil societies. In my view, this has something to do with diverse Islamic interpretations, particularly the relationship between Islam and democracy. In this regard, I would like to present Daniel Price's taxonomy on Islam and democracy. ${ }^{17}$

${ }^{14}$ Ibid.

${ }^{15}$ Philip Oxhorn, When Democracy Isn't All that Democratic: Social Exclusion and the Limits of the Public Sphere in Latin America, North South Agenda Paper 44. Coral Gables, Fla.: North South Center at the University of Miami, April 2001.

${ }^{16}$ Partha Chatterjee, "A Response to Taylor's 'Modes of Civil Society'," Public Culture, Vol. 3. (1) Fall, 1990.

${ }^{17}$ Daniel E. Price, Islamic Political Culture, Democracy and Human Rights: A Comparative Study (Westport, Connecticut: Praeger, 1999). 
Price offers two categories of Islamic political doctrine in terms of whether or not it is able to facilitate democracy. According to him, there are a number of factors within Islam that either support or oppose democracy. I will begin with those which support it. It is believed that the Qur'an, especially its early (Meccan) verses, contains a lot of favorable references to democracy, individual autonomy, and the desirability of universal participation by all members of the community in matters of governance and policy. At least, there are four factors that work for democracy. First, shüra, which translates into consultation. This notion implies that the leaders must consult with the citizens before making policies or taking major actions. Consultation, however, does not necessarily translate into representative government and free elections, as it has a broad meaning from direct democracy to consulting with a small group of elites selected by the regime to represent the citizenry. A second democratic principle inherent in Islam is ijma ${ }^{6}$, or consensus, which means that important policies should have the support of a significant segment of society. Consensus may indicate the support of a majority and expressed through referenda or a monarch who claims that God because he has ordained his rule the people agree with his policies. Ijtihàd, or individual discretion, is the third element in Islam that supports democracy. It means that each individual has autonomy to interpret Islam even with regard to socio-political life. Thus, the state cannot interfere with this autonomy. This element is very important, since democracy is impossible without a degree of individual autonomy from the state. The other important components of democracy, such as equality and participation, figure as the fourth feature in Islam. These components act as a foundation where all humans are partners and equal before God. They may fully participate in social life. These factors are a guide that requires Muslim adherents wherever they live to embrace democracy.

Besides the supportive factors of democracy, Price contends that there are other factors that may be regarded as being against democracy. ${ }^{18}$ First is the primacy of the shari $a$. This premise asserts that shari'a, or Islamic law, is superior. Some political groups in the Muslim countries, which are aspiring for an Islamic state, claim that the nature of the state is secondary to the implementation of shari'a. Consequently, authoritarian

${ }^{18}$ Ibid. 
government would be acceptable if it results in the application of shari' $a$. The role of non-Muslims in an Islamic democracy is the second element. As leadership position in a democracy is open to every citizen, regardless of religious affiliation, it is still uncertain whether or not Jews and Christians (both are considered "protected" citizens, or żimmi) can avail themselves of this right. Finally, the tendency to support the authoritarian rule has been widespread throughout Muslim history. There is a lack of democratic as opposed to despotic rule. By and large, religious scholars and judges claimed that order and security were preferable over the disorder that might follow a revolt against authoritarian rule.

In other words, Price's taxonomy above has led to two sketches. Firstly, those who favor the supportive factors of democracy may accept the notion that in order to build democracy, state initiative is necessary. Those who espouse democratic views based on the oppositional factors of democracy in Islam may expect little from the state. Indeed, they reject collaboration with the authoritarian state to establish democracy. Secondly, it may be said that the group which claims that there are supportive factors of democracy in Islam will not regard the separation between political society and civil society as significant. While for the group that emphasises the oppositional contradicting factors of democracy in Islam, on the other hand, will recognise the division between political society and civil society.

The question that further arises is: Could we apply the abovementioned categorisation to both Islamic groups in Indonesia disputing over the concept and to represent Muslim civil society? The following discussion will try to answer this.

\section{Muslim Civil Society in Indonesia: Perspectives and Experiences}

It is often claimed that a strong middle class and a well-developed civil society are necessary conditions for democratisation. Therefore, some attention has been given to building a strong middle class and civil society in Indonesia in the last few decades. The emergence of "Muslim civil society" in Indonesia, sometimes also identified as the Muslim middle class, is actually the result of the policies of the New Order regime (19661998). As the project of "depoliticising Islam" has partly achieved its goal, 
the government sought to compensate by touting its "Islamic" credentials before the Muslim Indonesian population. One policy responsible for the emergence of "Muslim civil society" was religious education. ${ }^{19}$ Due to their well high education, "Muslim civil society" eventually penetrates all sectors of social life, e.g., the bureaucracy, private companies, and the armed forces. Although they are loyal to the government programme of sustainable development, they have not diminished their criticism of state hegemony.

As "Muslim civil society" may refer to a number of Muslim organisations in Indonesia, it is uncertain which one of them represents true and real civil society. For the purpose of this study, at least two Muslim organisations were contesting to represent Muslim civil society in Indonesia: ICMI and NU. Both groups have their own theorists of civil society, e.g., Nurcholish Madjid, Dawam Rahardjo (ICMI); and Abdurrahman Wahid, Muhammad Hikam (NU). This alignment accorded with these persons' respective understandings of civil society. The two Muslim mass organisations have contributed concretely to civil society in Indonesia. Given the main characteristic of civil society as defined in this article is its dual dynamic, the discussion below will show how these two groups struggled for civil society in Indonesia. Whether or not their attempts were successful, civil society during Soeharto era remained weak. This was entirely due to the nature of the New Order regime, however, which ruled the country tyrannically and repressed all potential threats.

\section{Participation from within: ICMI's Efforts to Advance Civil Society}

Founded in 1990, the ICMI was an icon of reconciliation between the state and Islam after two decades of antagonism. Wertheim has noted that although they form a majority Indonesian Muslims typically have behaved more like a minority, particularly under the Soekarno and Soeharto regimes. ${ }^{20}$ By 1968, tension between government and Islam was openly acknowledged; from then on, Islamic political parties and Muslim activists appeared ever more clearly in opposition, and with the

${ }^{19}$ Muslim Abdurrahman, "Muslim Civil Society di Indonesia: Siapakah yang Memerankannya di Masa Depan?.”

${ }^{20}$ W.F. Wertheim, "Indonesian Moslems under Sukarno and Suharto: Majority with Minority Mentality," Studies on Indonesian Islam, Occasional Paper no. 19. Centre for Southeast Asian Studies, University of North Queensland Australia, 1986. 
general election of 1971 Islam established itself as the chief popular voice against the regime. ${ }^{21}$ Accordingly, the relationship between Islam and the state became more distant. The Muslim community was politically marginalised.

The founding of ICMI symbolically meant the elimination of mutual suspicions between Islam and the state. In other words, the trauma of antagonism would be removed from Indonesian Muslims' minds. In an interview, Nurcholish Madjid, a late Muslim prominent intellectual, warned of the dangers of the outsider mentality combined by the rising number of Muslim intellectuals. ${ }^{22}$ According to him, these Muslim intellectuals could potentially adhere to a kind of "oppositionalism" that regarded the government as bad in every respect. This situation easily led to conflict. In this regard, ICMI's close connection with the bureaucracy had the effect of facilitating the vertical mobility of Muslims. This in turn lessened their feelings of alienation in their own country. Their participation and their sense of belonging to the country would as a result promptly increase. Similarly for Madjid, Dawam Rahardjo, a leader of ICMI, suggested that the creation of ICMI would help remove the label of opposition attached to the Muslim community. Rahardjo argued that Muslims should not oppose participation within the state. In view of ICMI's close relationship with the state, Rahardjo thought, ICMI could influence government policies for the sake of the people. He felt that ICMI would remain critical but not oppositional. According to Rahardjo, the standpoint as the opposite would just make Muslims suffer, for it would disqualify them from participation. ${ }^{23}$

ICMI's accommodation by the state signified that Islam in Indonesia was welcomed to the center of power for the first time in four decades after the independence of Indonesia in 1945. It meant that, while other elements in Indonesian society were not yet treated the same, Muslim figures (ICMI) were allowed to enjoy limited civil rights and controlled

${ }^{21}$ Ruth McVey, "Faith as the Outsider: Islam in Indonesian Politics," in James P. Piscatori (ed.), Islam in the Political Process (Cambridge: Cambridge University Press, 1983)

${ }^{22}$ Nurcholish Madjid, "Suatu Saat ICMI akan Diterima Semua Pihak," in Nasrullah A. Fauzi (ed.), ICMI: Antara Status Quo dan Demokratisasi.

${ }^{23}$ Dawam Rahardjo, "Mereka tidak Konsisten Memandang ICMI," An Interview in Nasrullah Ali-Fauzi (ed.), ICMI: Antara Status Quo dan Demokratisasi. 
political rights. ${ }^{24}$ Both the access to a number of high official positions in the bureaucracy and, most importantly, the freedom to express Islamic identity, even at the state level, were basic rights which they had never possessed. It may be said that with the presence of the ICMI, the history of the Muslim community under the Indonesian New Order shifted from the coerced marginalisation to the controlled inclusion. In fact, the sense of returning power led the ICMI to enjoy the virtual inclusion. That is why they did not view any urgency to demand more civil rights and political rights. Alternatively, they actively offered a variety of programs that related to the struggle for socio-economic rights, ${ }^{25}$ since there has been a deep economic inequality in Indonesia.

It is important to note here that the ICMI had attempted to pressure for democratisation and human rights. However, its efforts were limited to holding discussions and seminar papers. Almost no action was carried out against the state. Indeed, some authoritarian state policies (e.g., the banning of the presses) drew less attention. Consequently, the ICMI attracted much criticism. ${ }^{26}$ One criticism since its inception has been that the ICMI was too involved in government policies. It was widely assumed that the ICMI was merely a state corporatist organisation designed to help Soeharto control the political system. ${ }^{27}$

In reply to some criticisms of its lack of action against state policies, Rahardjo affirmed, "ICMI is not a political party that produces political statements as well as political actions. What ICMI wants to

${ }^{24}$ What ICMI had at that time was basically limited and controlled rights. CIDES, a think tank of ICMI, had once organised a discussion on human rights in 1992, but the police came and stopped the discussion.

${ }^{25}$ Among others, the sponsorship for the founding of an Islamic Bank, the support for small entrepreneurships, the promotion of the education of science and technology in pesantren, the dissemination of scholarships information, the initiating of mosque libraries, the calling for books donations, the influence on the government policy of the poverty elimination program, and the drafting for the anti-monopoly law.

${ }^{26}$ In the eye of Abdurrahman Wahid, ICMI is sectarian and non-inclusive, since it subordinates national interests to the group interest. See, Wahid, Abdurrahman, "ICMI Memang Sektarian, Kok," in Lukman Hakiem, Tamsil Linrung, Mahmud F. Rakasima (eds.), Mereka Bicara tentang ICMI: Sorotan 5 Tabun Perjalanan ICMI Jakarta: Amanah Putra Nusantara, 1995).

${ }^{27}$ William Liddle, "The Islamic Turn in Indonesia: A Political Explanation," Journal of Asian Studies, vol. 55, (3), 1996. 
do is to direct Muslim citizens to participate in organising the state [penyelenggaraan negara]." 28 Amien Rais, one of the ICMI leaders, reacted to the criticisms by saying, "ICMI has a distinct method and prefers the effective way to build democracy. [The] ICMI does not want to collide with the 'big wall', for it is analogous to suicide." Rais further mentions that the criticisms were simply a provocation to drive the ICMI into opposition against the state, thereby benefiting ICMI's critics. For Rais, the state-Islam antagonism within the past Indonesian history has taught ICMI to avoid becoming the next victims. ${ }^{29}$ The foregone illustrations demonstrate how the ICMI has developed its relationship with the state. This leads to the question: How does the ICMI define its concept of civil society in this context? How can there be civil society without opposition to the authoritarian regime? Below I would like to present ICMI's perspectives on civil society, mostly as articulated by Dawam Rahardjo and Nurcholish Madjid.

Initially, Rahardjo did not identify the term civil society, or masyarakat madani, with ICMI. ${ }^{30}$ Yet, ICMI was described as a promising agent of civil society, offering the indicators of why ICMI deserved to be considered civil society. "ICMI is composed of a pluralist community, democratic and equal. It is pluralist for recognising the diversity as a positive factor...It is democratic because musyawarah [deliberation] was agreed as a method to make any decision regarding the collective problems and interests. And it is equal since all agreed to acknowledge that everyone, all human beings have the same rights and duties. And because of its plurality, ICMI's civil society was characterised as bearer of the mission of integration in the fields of politics, social and cultural."

According to Rahardjo, Islam must be integrated with the state. ${ }^{31}$ This integration would generate participation, which Rahardjo identified as another characteristic of ICMI's civil society. Therefore, one of ICMI's duties is to direct Muslim citizens to participate. The participation at the state level is necessary because political institutions (parliament) and parties are weak while the state is powerful, which, in

${ }^{28}$ Dawam Rahardjo, "Visi dan Misi Kehadiran ICMI: Sebuah Pengantar."

${ }^{29}$ Amien Rais, "ICMI Harus Menyentuh Akar Rumput Umat," An Interview in Nasrullah Ali-Fauzi (ed.), ICMI: Antara Status Quo dan Demokratisasi.

${ }^{30}$ Dawam Raharjo, "Visi dan Misi Kehadiran ICMI: Sebuah Pengantar."

${ }^{31}$ Dawam Rahardjo, "Mereka Tidak Konsisten Memandang ICMI." 
turn, may lead to the weakening of civil society. ${ }^{32}$ Rahardjo seems to be saying that empowering civil society is tantamount to integration and participation in the state structures. In this logic, it is clear why then as a non-governmental organisation ICMI has deemed itself the agent of civil society. If "integration" and "participation" are the key concepts of ICMI's civil society, it is no wonder if ICMI's civil society may shift to political society. Rahardjo states that "the rising civil society, whose basic component is Muslim community as the majority of the population in Indonesia, will set up socio-cultural bases to help the state grow. Its success can be identified if all the state institutions and political system can work well." Therefore, Rahardjo regarded ICMI as an intermediary institution between the state and society and between religion and the state, and on the other hand, as the partner of the government in development. ${ }^{33}$ Seen from this perspective, it is understandable why ICMI as civil society did not represent an opposition even to the New Order authoritarian regime.

Based on the concept of ICMI's civil society above, the question may arise as to how ICMI could struggle for democracy and against the injustices perpetrated by the regime. It seemed that by perceiving an opposition action as taboo, ICMI would seek critical persuasion. ${ }^{34}$ However, there is no clear evidence that this has been successful in securing the essential civil rights ${ }^{35}$ and the inclusive political rights. ${ }^{36}$ As

${ }^{32}$ Dawam Rahardjo, “ICMI, Masyarakat Madani, dan Masa Depan Politik Indonesia: Sebuah Catatan Akhir."

${ }^{33}$ Ibid.

${ }^{34}$ Adi Sasono, one of ICMI figures, explains why there should not be the radical opposition to the government. He warns that this would generate instability and eventually lead the power holders to remain authoritarian. It seems that he was optimistic that the regime would change. See, Adi Sasono, "Jangan Terjebak Pemikiran Konfrontatif," an interview in Nasrullah A. Fauzi (ed.), ICMI: Antara Status Quo dan Demokratisasi.

${ }^{35}$ After being accused of slandering President Soeharto in speeches he gave during a visit to Germany in 1995, Sri Bintang Pamungkas (an activist of ICMI) was expelled from the parliament. This was seen as evidence for the thesis that ICMI does not eagerly fighting for civil rights. ICMI offered little resistance to the expulsion.

36 "The 27 July 1996 event" is perhaps a clearer indication that the regime continued to repress political rights. In that event, Soerjadi, the former chairman of Indonesian Democratic Party (PDI), supported by the military, attacked the office of PDI belonging to Megawati, the chief of the party at that time. The office was then 
Hefner (1997) argued, "[T]he participation of Muslims in government says little about which Islamic principle will be implemented in policy and even less about how Islam might contribute to democratisation." ${ }^{\text {37 }}$ Moreover, some political observers saw the existence of ICMI as a barrier to a vigorous civil society and democratisation in Indonesia. ${ }^{38}$ However, as noted by Arbi Sanit and Mahasin, ${ }^{39}$ ICMI's presence in the bureaucracy was symbolically a civil force vis-à-vis the military; it created a new equilibrium in Golkar, the ruling political party, which was previously dominated by the military for the long term. Perhaps, it suffices to say that by eschewing the demand for civil rights and political rights, ICMI failed to represent the real civil society. Their relative success in the struggle for socio-economic rights was enough to label ICMI as a quasi-civil society, but insufficient to identify it as qualified civil society.

Why was ICMI's civil society not in opposition? Let us see how, in another respect, Nurcholish Madjid's account of civil society explains the absence of opposition in ICMI's civil society. I will argue that it has something to do with Price's category of supportive factors of democracy. This category departs from the claim that Islam has democratic dictates.

Madjid's conception of civil society refers mostly to the experiences of Madinan society in early Islam. Madjid says, "The term madinah, in the modern sense, points to the spirit and meaning of civil society, an English term which meant polite society, civilised, and orderly in the state with a good system." ${ }^{40}$ Madjid's reference of Islamic civil society to an early

occupied and closed down. Subsequently, Megawati was kept from participating in the 1997 election, while Soerjadi was welcomed to represent the party.

${ }^{37}$ Robert W. Hefner, "Islamization and Democratization in Indonesia," in Robert W. Hefner and Patricia Horvatich (eds.), Politics and Religious Renewal in Muslim Southeast Asia.

${ }^{38}$ Fachry Aly, "Keharusan Demokratisasi dalam Islam Indonesia," an Interview in Nasrullah A. Fauzi (ed.), ICMI: Antara Status Quo dan Demokratisasi.

${ }^{39}$ Arbi Sanit, "Yang Kecil Tidak Bisa Lama Menunggu," An Interview in Nasrullah Ali-Fauzi (ed.), ICMI: Antara Status Quo dan Demokratisasi; Aswab Mahasin, "Konsolidasi Berlebihan bisa Mengkhawatirkan," An Interview in Nasrullah Ali-Fauzi (ed.), ICMI: Antara Status Quo dan Demokratisasi.

${ }^{40}$ Nurcholish Madjid, "Prinsip Kemanusiaan dan Musyawarah dalam Politik Islam," in Nurcholish Madjid, Islam Agama Kemanusiaan: Membangun Tradisi dan Visi Baru Islam Indonesia (Jakarta: Paramadina, 1995); "Suatu Saat ICMI akan Diterima Semua Pihak." 
Islam in Madina attracted criticisms, mainly from Baso. According to him, what led Madjid to explain the concept of civil society in the light of the experiences of early Islam were twofold. Firstly, Madjid was influenced by the understanding of the unity of Islam and the state. Secondly, a demand in the political arena directed Madjid to interpret Islam in a way that integrates it to the state in the name of "Islamic values." 41

Some may wonder if Baso's criticisms are appropriate. In my opinion, these Baso's allegations are unfounded if one considers that as early as 1970s Madjid was popularly known as the pioneer who advocated the reformulation of the fundamental Islamic postulates about God, man and the world, and their relationships in the light of new political realities. ${ }^{42}$ In fact, it was Madjid who first introduced the separation between Islam and politics with his slogan "Islam Yes, Islamic Party No." The fact that Madjid's conception of civil society refers to early Islam in Madina, it does not necessarily tell us that Madjid was a subscriber of the notion that Islam and the state must be united. In my opinion, Madjid's references to the history of Islam were those of a Muslim intellectual used to discussing the socio-political problems of Indonesia from an Islamic perspective.

How or why was Madjid's conception of civil society related to the Madinan society in the Prophet Muhammad's time? The answer is very simple. It has much to do with Madjid's definition of civil society, which is closely related to the concept of civility. ${ }^{43}$ Civility was defined as a quality of life, which consisted of tolerance, the rejection of personal infallibility, human appreciation, and other high values. Meanwhile, it was believed that Madina under Muhammad was prosperous, democratic and participial. What is more, it has represented an ideal form of civilised life that had been ever in the world history. In short, civil society or masyarakat madani was associated with the combination of Madinan society and civility or civilisation in Madjid's conception. It is obvious that the

${ }^{41}$ Ahmad Baso, Civil Society versus Masyarakat Madani.

${ }^{42}$ Muhammad Kamal Hassan, Muslim Intellectual Responses to "New Order" Modernization in Indonesia (Kuala Lumpur: Dewan Bahasa dan Pustaka Kementrian Pelajaran Malaysia, 1982).

${ }^{43}$ Nurcholish Madjid, "Dinamika Budaya Pesisir dan Pedalaman: Menumbuhkan Masyarakat Madani,” in Abdullah Hafiz, et.al. (eds.), HMI dan KAHMI: Menyongsong Perubahan, Menghadapi Pergantian Zaman (Jakarta: Majelis Nasional KAHMI, 1997). 
prophet is not the ruler likely to govern repressively. So, given Madjid's concept of civil society refers mainly to Madinan society at the time of the Prophet Muhammad, it goes without saying that there should not be an opposition; as how could be there an opposition to the prophet?

Madjid actually realised that ICMI should have a control role, though a very limited one. He suggested that there should be a dynamic of "checks and balances" on the part of the ICMI to control the state. ${ }^{44}$ However, instead of pointing out the significance of opposition against the despotic regime in his concept of civil society, Madjid, like many ICMI figures, proposed a lenient approach. The reason behind this approach is, according to Madjid, the three characteristics of civil society. Firstly, it is a beneficial rather than destructive force. Secondly, it has a negative side effect, that is chaos, which in turn led to the emerging of an authoritarian powerful figure. Thirdly, the possibility that it may become fragmented once government legitimacy decays. ${ }^{45}$ Seen in this light, it is easily understood that in its attempt to build democracy, the ICMI favored civil society to persuade the state from within, and by so doing supported it.

The above discussions recall Walzer ${ }^{46}$ and Oxhorn. ${ }^{47}$ It was argued that civil society is organically weak, and thus needs to be strengthened. Due to civil society obstacles like inequality, fragmentation and fitfulness, the effort to strengthen civil society is mostly a state initiative. This is because the democratic state not only allows civil society to develop, but supports and facilitates it. In authoritarian regimes, where political inclusion is not yet established and a variety of institutions are not stable enough for negotiating the limits on state actions, the progress of civil society in gaining its autonomy from the state requires struggle or opposition. Seen from this perspective, I would like to reject Baso's argument that the group's use of masyarakat madani (ICMI) reflects typically a Hegelian concept of civil society. ${ }^{48}$ In my opinion, those ICMI Islam."

${ }^{44}$ Madjid, Nurcholish, "Prinsip Kemanusiaan dan Musyawarah dalam Politik

\footnotetext{
${ }^{45}$ Nurcholish Madjid, "Dinamika Budaya Pesisir dan Pedalaman: Menumbuhkan Masyarakat Madani."

${ }^{46}$ Michael Walzer, "Rescuing Civil Society," Dissent (Winter), 1999.

${ }^{47}$ Philip Oxhorn, When Democracy Isn't All that Democratic.

${ }^{48}$ Ahmad Baso, Civil Society versus Masyarakat Madani.
} 
figures simply misuse the concept of civil society (masyarakat madani), which concept is fit only for countries where democratic regimes are firmly established, but not for a country like Indonesia under Soeharto's despotic rule.

\section{Opposition to State Hegemony: NU's Resistance as Means of Civil Society}

Several scholars, like Hikam and Falaakh, have mentioned the public performance of NU either as a potential or an emerging Muslim civil society in Indonesia. ${ }^{49}$ Indeed, the NU was deemed as the last bastion of civil society in Indonesia. Describing the 1984 NU Congress ${ }^{50}$ as the foundation stone for NU's civil society, Abdurrahman Wahid, the chairman of the NU for three terms (1984-1999), was the main actor who involved NU in the building of civil society. In fact, NU's civil society cannot be distinguished from Wahid's views and his individual actions. Wahid was considered the icon that by habit came to represent NU's civil society. Wahid's views and his individual protests were deemed the dynamics of NU's civil society vis-à-vis the state. Before his election to be a chairman of the NU in 1984, the focus of Wahid's views was already very much on human rights, tolerance, pluralism and egalitarianism. His terms in office showed much evidence for the dual dynamic of civil society. This dynamic of NU's civil society perhaps may be classified into three categories. (1) resistance to the state intervention; (2) demand for inclusive politics; and (3) protest against anti-democratic policies.

Obviously, all these were attempts to gain civil rights and political rights, and as we shall see below, the opposition in many ways became the main feature. NU's resistance to the state intervention is probably the clearest evidence for the thesis that NU was the most representative Muslim civil society in Indonesia. It may be said that this attempt proved NU's success in building civil society. There were at least two cases where one may consider NU was a thriving civil society. Firstly, the

${ }^{49}$ Muhammad AS. Hikam, 1994. "Khittah dan Penguatan Civil Society di Indonesia: Sebuah Kajian Historis Struktural atas NU sejak 1984"; Muhammad Fajrul Falaakh, "NU dan Cita-cita Masyarakat Madani," Pikiran Rakyat, 1 Februari 1996.

${ }^{50}$ The Congress agreed to withdraw NU from formal Indonesian political arena, in which NU was the main element of The Unity Development Party (PPP), and returned to its early 1926 charter (khittah) as a Muslim social organisation that focused on social development and social welfare. 
1994 NU Congress that elected Wahid for the third time was not just a victory over Wahid's opponents within NU, but also a victory over the state intervention. There were several political motives that sought to overthrow Wahid's outspoken defense of democracy and human rights from NU leadership. Fealy explained that prior to departing for the congress, NU branch delegates were summoned to local government offices and military officials, and had been instructed not to vote for Wahid. ${ }^{51}$ Some Wahid supporters were given inducements to change their allegiance, while others were threatened with reprisals. Various media outlets closely connected to the government, or the Soeharto family, took anti-Wahid stance as well. Faced with these fierce challenges, NU's ability to organise its internal solidity and to resist the external interferences clearly reflected the strong autonomy of NU's civil society.

The second example of NU's resistance was NU's rejection to the subordination of religion to the state, in the case of the commencement and the end of Ramadan fasting in particular. To determine the commencement and the end of this religious festive, NU's method was to use direct observation (r'y yah) instead of astronomical calculation (bisab). The latter was used officially by the government as a legitimate method. This stance provided evidence of NU's rejection of the subordination of religion to the state. ${ }^{52}$ In fact, the different methods used had led NU to celebrate Idul Fitri (Islamic festive) on different days than what the government decided for three consecutive years in the early 1990s.

NU's demands for inclusive politics were expressed at a mass rally (rapat akbar) at the Senayan Sport Stadium in Jakarta on March 1, 1992.

${ }^{51}$ Greg Fealy, "The 1994 Congress and Aftermath: Abdurrahman Wahid, Suksesi and the Battle for Control of NU," in Greg Barton and Greg Fealy (eds.), Nabdlatul Ulama, Traditional Islam and Modernity in Indonesia (Clayton: Monash Asia Institute, 1996).

${ }^{52}$ Another evidence that may be mentioned here is Wahid's criticism of the Indonesian Ulama Council (MUI). For Wahid, this institution simply reflected the subordination of religion to the state. Similarly, Wahid paid more attention to the marriage of a Confucian couple which was rejected by the government. He frequently came to the Pengadilan Tata Usaha Negara/PTUN (State Administrative Court) of Surabaya, where this case had been examined, to support their suit. By his presence, Wahid expressed sympathy with the minority and the opposition to the state, which always attempted to govern, define and regulate the spirituality and beliefs of people. See, Isre (ed.), Tabayun Gus Dur: Pribumisasi Islam Hak Minoritas Reformasi Kultural (Yogyakarta: LKiS, 1998). 
Two million of NU members were expected to attend this rally. Yet, only 150.000 to 200.000 people came. According to Wahid, the armed forces prevented many thousands more from coming to Jakarta. ${ }^{53}$ The purpose of this rally was not just to celebrate the organisation's anniversary, but also to support NU's stance on more inclusive politics through a reiteration of loyalty to the Pancasila (five pillars of Indonesian ideology). In this rally, the NU announced final commitment to the Pancasila, which represented an essential political compromise, as the basis of the state, and asserted that Islam should not be the formal basis of the state. For the NU, the Pancasila and its stress on religious and ethnic tolerance was a necessary precondition for the development of a genuine democracy in Indonesia. ${ }^{54}$ According to Ramage, there were several reasons for this pledge of loyalty to the Pancasila, which generally express NU's aspiration to the inclusive politics. ${ }^{55}$ Firstly, Wahid was searching for a way to avoid endorsing President Soeharto for a fifth five-year term in office. Secondly, Wahid was deeply worried by the formation of the new government-sponsored Islamic organisation (ICMI), and was anxious to demonstrate that the umma (Indonesian Muslims) still supported his leadership and the ideal of an inclusive, democratic Islam. Thirdly, Wahid perceived a rising tide of sectarianism and fundamentalism in Indonesia and was anxious to portray the NU as representative of a non-sectarian understanding of Islam.

NU's protests (precisely Wahid's own maneuver) against antidemocratic policies were clearly evident in the "Monitor Affair". Ramage had illustrated this case as one of the disturbing paradoxes: the simultaneous emergence of thoughtful, tolerant, pluralism and democracy coupled with increasing social intolerance and sectarianism. ${ }^{56}$ The affair started with the publication of the results of a readers' poll of

${ }^{53}$ Daniel Dhakidae, "Langkah Non Politik dari Politik NU," in Ellyasa KH. Dharwis, Gus Dur, NU, dan Masyarakat Sipil (Yogyakarta: LKiS, 1994).

${ }^{54}$ Douglas Ramage, "Democratization, Religious Tolerance and Pancasila: The Political Thought of Abdurrahman Wahid," in Greg Barton and Greg Fealy (eds.), Nabdlatul Ulama, Traditional Islam and Modernity in Indonesia (Clayton: Monash Asia Institute, 1996).

${ }^{55}$ Ibid.

${ }^{56}$ Douglas Ramage, Politics in Indonesia: Democracy, Islam and the Ideology of Tolerance (London and New York: Routledge, 1995). 
most-admired public figures in the October 1990 edition of the weekly tabloid Monitor. President Soeharto was placed first, while the Prophet Muhammad was the eleventh. This poll immediately provoked wide outrage of Muslims, including Amien Rais and Nurcholish Madjid, for its extreme insensitivity towards Islamic beliefs. The outrage was amplified by the fact that the tabloid was part of the Catholic-owned Gramedia publishing group. Due to a number of objections and protests from the Muslim community, the government quickly banned the tabloid and sentenced Arswendo Atmowiloto, the tabloid chief editor, to five years in prison because of this socio religious affair.

In the light of the Muslim protests and the press banning, Abdurrahman Wahid was the only major Muslim leader to argue for calm in this affair. In an interview, Wahid said that "whatever one may feel concerning how the prophet was depicted in the Monitor's poll, the right to publish cannot be infringed upon." If Muslims are insulted, Wahid argued, they should simply boycott the tabloid. Under no circumstance, Wahid declared, could he accept the banning and revocation of the fundamental right to free speech and publication of anyone, by anyone, in any place. ${ }^{57}$ Although the government did not respond to his protests, Wahid's demand for civil rights clearly reflected his commitment to democracy.

It is interesting to note here that in the second half of 1996 until the downfall of Soeharto in May 1998, Wahid became increasingly lenient towards the regime. Barton and Feillard explained that Wahid clearly felt that desperate measures were called for. ${ }^{58}$ The violent assault on Megawati loyalists occupying the PDI building in Jakarta in July 1996 and the rioting that followed in Situbondo (October 1996) and Tasikmalaya (December 1996), both cities well-known as a base of NU support, no doubt added to the sense that Soeharto and the armed forces might be prepared to take extraordinary measures against NU and its "recalcitrant" chairman. In this regard, what Anita Harrison said in her memo may be valid. According to her, Wahid has always put the safety of his organisation above his commitment to democratic change, and if

${ }^{57}$ Ibid.

${ }^{58}$ Greg Barton and Andree Feillard, "Nahdlatul Ulama, Abdurrahman Wahid and Reformation: What Does NU's November 1997 National Gathering Tell Us?," Studia Islamika Indonesian Journal for Islamic Studies, vol. 6 (1), 1999. 
a formal challenge to Soeharto meant closing off options for the NU, he would not do it. Therefore, by early 1997, Wahid had successfully negotiated a rapprochement with the regime. ${ }^{59}$ However, his handshake with President Soeharto in November 1996 and his move to officially "introduce" the President's daughter, Siti Hardiyanti Rukmana or Tutut, to the NU masses at several large regional rallies shocked many of his supporters, who thought that Wahid had changed affiliation. For that reason, Wahid paid dearly in terms of personal credibility. ${ }^{60}$

In an interview soon after his handshake with President Soeharto, Wahid explained that Soeharto had already made "a correction over a correction." ${ }^{61}$ When Soeharto approved the founding of ICMI, said Wahid, he was actually correcting his earlier policy during the 1970s, when Islam had been underrepresented. Unfortunately, this correction was exploited, for the ICMI was deemed the sole organisation that could represent Islam, and hence it needed a re-correction. This time, according to Wahid, Soeharto had made a new correction by recognising that the NU also could represent Islam in Indonesia. This fact may have meant that Wahid started to notice a gradual change within the regime towards inclusive politics. Indeed, he believed that, although Soeharto was elected in the 1998 general session of Majelis Permusyawaratan Rakyat/MPR (The People Assembly) for the seventh term, a significant change would take place in democratic life. Was this change due to pressure from Wahid or the NU? It is difficult to say, but it must be believed that such a change would never have occurred had there been no cause. And Wahid, together with his organisation was obviously one of the causes.

Opposition and autonomy typically characterised the dynamics of NU's civil society. The question is how does the NU define civil society? What are the main elements of this definition? Falaakh, one leader of the NU, emphasised four features of NU's social aspirations, that is, al-tawassut wa'lit'idāl (moderation), tasämụ (tolerance), tawāąun, (egalitarianism), and al-amr bil'-ma'rüf wa-naby 'an al-munkar (social criticisms: to promote the

${ }^{59}$ Edward Aspinall, Herb Feith, and Gerry van Klinken, The Last Days of President Suharto (Clayton: Monash Asia Institute, 1999).

${ }^{60}$ Greg Barton and Andree Feillard, 1999. "Nahdlatul Ulama, Abdurrahman Wahid and Reformation: What Does NU's November 1997 National Gathering Tell Us?."

${ }^{61}$ Isre (ed.) Tabayun Gus Dur: Pribumisasi Islam Hak Minoritas Reformasi Kultural. 
good and to forbid the evil). The last feature, particularly to forbid the evil, seems broadly more compatible with the opposition. ${ }^{62}$ Autonomy was also stressed in NU's civil society. In a seminar oration, Wahid expressed the essence of civil society, "Any group designed for struggling the autonomy of the society could be identified as civil society. [The autonomy here is] meaning that how to make people independent from the state. This is the essence of civil society. Civil society focuses on the struggle of the society position vis-à-vis the state." ${ }^{\prime 3}$ Viewed simply, it pertained to social functions. So, as long as social functions exist [in any social group], that is, to strengthen the position of the society, such a group may be labeled civil society". Based on his definition of civil society, Wahid did not recognise ICMI as civil society, for it sought an integration. Given that pluralism is one characteristic of civil society, Wahid emphasised NU's pluralism by saying that "NU does not need to struggle for an Islamic society, but for Indonesian society where Muslim believers are free to perform the religious duty." ${ }^{64}$ The NU and the ICMI are actually Muslim organisations and hence their memberships consist of Muslim adherents. However, compared to ICMI's objective of improving the quality of Muslim citizens, NU's objective is for all Indonesians.

Opposition and autonomy are much clearer in the notions of Hikam. ${ }^{65}$ What is more, Hikam derived a number of theories on civil society from Western perspectives. ${ }^{66}$ Realising that democracy would be difficult for the state to implement, he proposed a strategy of civil society empowerment, since it was a main precondition of democracy. This strategy begins with a serious attempt to create a free public sphere that includes all the potentialities of society; while at the same time there are continuous criticisms of the inequalities. Although Hikam did not describe the state as the enemy, he suggested that civil society must

${ }^{62}$ Muhammad Fajrul Falaakh, "NU dan Cita-cita Masyarakat Madani."

${ }^{63}$ Abdurrahman Wahid, "Islam dan Civil Society: Pengalaman Indonesia," Halqah, no. 6, 1998.

${ }^{64}$ Ibid.

${ }^{65}$ Muhammad AS. Hikam, Demokrasi dan Civil Society (Jakarta: LP3ES, 1996).

${ }^{66}$ This is not surprising, since Hikam obtained his $\mathrm{PhD}$ degree from University of Hawai'i, where he wrote his dissertation entitled "The State, Grassroots Politics and Civil Society: A Study of Social Movements under Indonesia's New Order (1989-1994)." This work dealt mainly with state-society relations and democratisation in Indonesia. 
control the excesses of the state. Hikam considered 'NU post return to the 1926 kbittah' was the cornerstone of NU's civil society in Indonesia. ${ }^{67}$

If opposition and autonomy are the main elements of NU's civil society, where does Islam figure in this context? Following Jose Casanova, ${ }^{68}$ Hikam highlighted the necessity to reinterpret Islam as a public religion. ${ }^{69}$ This means that Islam should not be profaned through their identification with efforts to seize state power; it must be anchored in civil society, not in state bureaucracies. From there it must work to inform public policy and discourse. Thus, Islam could participate in empowering society. Hikam also suggested the reinterpretation of the concept of umma, a term that referred specifically to the Islamic community, so that it can mean encompassing the border of religion. ${ }^{70}$ Viewed in this light, NU's civil society was set out from the factors within Islam that against democracy. Other NU figures, like Said Aqil Siradj, refused to refer civil society to Madinan society in early Islam because it was not as excellent as imagined..$^{71}$ The violence, even the expulsion of the Jews from Madina in the Prophet Muhammad's time and the claim that the Quraish tribe (Muhammad's clan) was superior, were thought to be incompatible with civil society. For the NU, it seems that to build Indonesian democracy should not necessarily refer to early Islam, but may be based on the modern or even Western experience.

Compared to ICMI's civil society, NU's civil society was more progressive with respect to the dual dynamic of civil society, which attempted the resistance to subordination to the state and the demand

${ }^{67}$ It is interesting to note here that, in July 1998 soon after the collapse of the New Order regime, the NU initiated a political party (Partai Kebangkitan Bangsa or National Awakening Party). Although Gramsci classified political parties as political society, this NU attempt may still be categorised within civil society empowerment, that is, the demand for the inclusion into national political structure. This is due to the lack of civil rights and political rights under the Soeharto regime, with only three political parties allowed. Muhammad AS. Hikam, "Islam and the Empowerment of Indonesian Civil Society."

${ }^{68}$ Jose Cassanova, Towards a Constructive Engagement of the Fundamentalist Challenge: The Concept of Publics Religion (Mass. Kuala Lumpur, 1996).

${ }^{69}$ Muhammad AS. Hikam, Demokrasi dan Civil Society.

${ }^{70}$ Ibid.

${ }^{71}$ Abdul Mun'im, D.Z., "Distorsi Terhadap Masyarakat Sipil," Khittah, No. 1, November 1999. 
for inclusion into national political structure. Although the ICMI and the NU share a legitimate perspective on civil society, it is apparent that the NU was credited with more effective resistance to the authoritarian regime and the democratisation of society from below while pressuring the authoritarians for change. This meant that NU's civil society gained symbolic victory in the contest to represent Muslim civil society in Indonesia.

It is important to note, however, that civil society's success in resisting state intervention does not automatically lead to a democratic system, even less able to a transformation of the authoritarian regime. In this regard, the recognition of the role of the state in structuring a democratic political climate is a necessary lesson in civil society and the state. Civil society requires a state that is both strong and self-limiting. It must be self-limiting in the sense that it does not monopolise society's powers, drawing all vital personnel, services, and enterprises to itself. The state must also be strong, in the sense that it is capable of safeguarding the freedom of association and initiative on which a vigorous public life depends. ${ }^{72}$ Moreover, as noted by Oxhorn, the structure of the public sphere depends on how the state conditions it through the relations it establishes with the actors of civil society. ${ }^{73}$ Oxhorn mentions two ways in which the state directly structures the public sphere. First, state institutions create both opportunities and incentives for different groups to organise and to attempt to influence policies. The degree of openness of state institutions determines the kinds of groups which have access and how such access is achieved. Second, the state conditions the public sphere through the provision of rights of citizenship. Important formal rights such as freedom of expression and association are obvious prerequisites for any public sphere to function democratically. Seen through these perspectives, it may be said that the ultimate success of civil society in creating a democratic political climate and upholding the supremacy of the law needs the good will of the state. Otherwise, it will never put the country even on the path to democracy.

\footnotetext{
${ }^{72}$ Robert W. Hefner, "A Muslim Civil Society?."

${ }^{73}$ Oxhorn, Philip, 2001. When Democracy Isn't All that Democratic.
} 


\section{Concluding Remarks}

Given that this article emphasises the diversity of Islamic interpretation of socio-political life, the differences between the ICMI and the NU in defining civil society, applying the term, and identifying the agent of civil society reflect their differences in viewing the relationship between Islam and democracy. The ICMI favored the factors within Islam that work for democracy; while the NU was concerned with the factors that went against democracy. In other words, the ICMI accepts democracy, deeming it compatible with Islamic teachings, but, on the other hand, the NU could only accommodate Islamic teachings in sociopolitical life, as long as there was no contradiction with democracy. Seen through this prism, while the ICMI clearly assumed a particular type of Muslim civil society, the NU contended that the same civil society that existed in the West should exist in Muslim society. This fact of Muslim civil society in Indonesia may reflect the divergence between the relativist and the universalist approaches. ${ }^{74}$

What was the condition of Muslim civil society in the postauthoritarian government, during the era of President Abdurrahman Wahid (1999-2001) in particular? Given the successive governments in the aftermath of the authoritarian Soeharto regime now have widely recognised the citizenship rights and people have enjoyed more civil rights and political rights than ever before, ${ }^{75}$ the emergence of strong civil society in the post-Soeharto Indonesia remains necessary given socioeconomic rights are declining. According to Oxhorn, the development of citizenship rights is intimately linked to the development of civil society, and where civil society is weak the social construction of citizenship rights are correspondingly narrower. ${ }^{76}$ Moreover, once civil rights and

${ }^{74}$ Chris Hann, "Introduction: Political Society and Civil Anthropology," in Chris Hann and E. Dunn (eds.), Civil Society: Challenging Western Models (London: Routledge, 1996).

${ }^{75}$ Indeed, in March 2000, President Wahid suggested that the People's Assembly (MPR) better withdraw the law that banned the Communist Party in Indonesia. However, this suggestion provoked many angry demonstrations, especially by Muslims.

${ }^{76}$ Philip Oxhorn, "Social Inequality, Civil Society and the Limits of Citizenship in Latin America," in Susan Eckstein and Timothy Wickham-Crawley (eds.), What Justice? Whose Justice? Fighting for Fairness in Latin America (Berkeley: University of California Press, 2003), pp. 35-63. 
political rights are recognised, citizenship would then continue to expand to include the social rights of citizenship associated with the modern welfare state (e.g. access to healthcare, various state policies to ensure a minimal standard of living, and so on).

In view of this, it may be asserted that the implementation of socio-economic rights to a large extent not depends on political legislation but on the social and economic policies of the state. The prolonged Indonesian economic crisis was a serious obstacle to the realisation of such rights. This situation, in turn, has opened the way to the resurrection of civil society and the demand to the state to pay attention more to economic recovery. This may actually presented an opportunity for the ICMI. Since socio-economic rights are rights that the state would have to take positive action to promote, the ICMI shall remind the government not to waste time dealing with unnecessary political issues and to concentrate on economic recovery. However, this was unlikely the case for the ICMI during the Wahid's presidency. Some observers were in doubt that the ICMI would be a potential civil society that well prepared to play a role in opposing the state, for the lack of opposition tradition within the ICMI itself.

The same was true for the NU. Many have expressed pessimism that the $\mathrm{NU}$ would be consistent to hold its stance as a robust civil society. ${ }^{77}$ As Abdurrahman Wahid, the former chairman of NU and an agent of civil society, became the Indonesia President and his colleague, Hikam, who was earlier known as the defender of the society's autonomy vis-à-vis the state, also became a minister in Wahid's cabinet, the NU, the mass organisation where Wahid comes from, was not keen on opposing or even criticising the government. All this shows that by the time Wahid was in the presidential office, both Muslim civil societies in Indonesia (ICMI and NU) were not able to act as agents of civil society and to play their respective particular roles effectively.

${ }^{77}$ Syafiq Hasyim, "Masa Depan Demokrasi dan Civil Society", Panji Masyarakat, vol. III, (30), 1999; Rumadi, “Civil Society dan NU Pasca Gus Dur”, Kompas, 5 November 1999. 


\section{BIBLIOGRAPHY}

Abdurrahman, Muslim, "Muslim Civil Society di Indonesia: Siapakah yang memerankannya di masa depan?," in Muslim Abdurrahman, Semarak Islam, Semarak Demokrasi, Jakarta: Pustaka Hidayah, 1996.

Aly, Fachry, "Keharusan Demokratisasi dalam Islam Indonesia," in Nasrullah A. Fauzi (ed.), ICMI: Antara Status Quo dan Demokratisasi, Bandung: Mizan, 1995.

Aspinall, Edward, Herb Feith, and Gerry van Klinken, The Last Days of President Subarto, Clayton: Monash Asia Institute, 1999.

Barton, Greg and Andree Feillard, "Nahdlatul Ulama, Abdurrahman Wahid and Reformation: What Does NU's November 1997 National Gathering Tell Us?," Studia Islamika Indonesian Journal for Islamic Studies, vol. 6 (1), 1999.

Baso, Ahmad, Civil Society versus Masyarakat Madani: Arkeologi Pemikiran Civil Society dalam Islam Indonesia, Jakarta: Pustaka Hidayah, 1999.

Bobbio, Norberto, "Gramsci and the Concept of Civil Society", in John

Keane, (ed.), Civil Society and The State: New European Perspectives, New York: Verso, 1988.

Cassanova, Jose, Towards a Constructive Engagement of the Fundamentalist Challenge: The Concept of Publics Religion, Mass. Kuala Lumpur, 1996. Chatterjee, Partha, "A Response to Taylor's 'Modes of Civil Society'," Public Culture, Vol. 3. (1) Fall, 1990.

Dhakidae, Daniel, "Langkah Non Politik dari Politik NU," in Ellyasa KH. Dharwis, Gus Dur, NU, dan Masyarakat Sipil, Yogyakarta: LKiS, 1994.

Falaakh, Muhammad Fajrul, "NU dan Cita-cita Masyarakat Madani," Pikiran Rakyat, 1 Februari 1996.

Fealy, Greg, "The 1994 Congress and Aftermath: Abdurrahman Wahid, Suksesi and the Battle for Control of NU," in Greg Barton and Greg Fealy (eds.), Nahdlatul Ulama, Traditional Islam and Modernity in Indonesia, Clayton: Monash Asia Institute, 1996.

Hann, Chris, "Introduction: Political Society and Civil Anthropology," in Chris Hann and E. Dunn (eds.), Civil Society: Challenging Western Models, London: Routledge, 1996. 
The Contested Representation of Muslim Civil Society in Indonesia

Hassan, Muhammad Kamal, Muslim Intellectual Responses to "New Order" Modernization in Indonesia, Kuala Lumpur: Dewan Bahasa dan Pustaka Kementrian Pelajaran Malaysia, 1982.

Hasyim, Syafiq, Masa Depan Demokrasi dan Civil Society," Panji Masyarakat vol. III, (30), 1999.

Hefner, Robert W., "A Muslim civil society? Indonesian Reflections on the conditions of its possibility," in Robert W. Hefner (ed.), Democratic Civility: The History and Cross-Cultural Possibility of a Modern Political Ideal, New Brunswick and London: Transaction Publishers, 1998.

----, "Islamization and Democratization in Indonesia," in Robert W. Hefner and Patricia Horvatich (eds.), Politics and Religious Renewal in Muslim Southeast Asia, Honolulu: University of Hawai'i Press, 1997.

Hikam, Muhammad AS., "Khittah dan Penguatan Civil Society di Indonesia: Sebuah Kajian Historis Struktural atas NU sejak 1984," in Ellyasa KH. Dharwis, Gus Dur, NU, dan Masyarakat Sipil, Yogyakarta: LKiS, 1994.

----, "Islam and the Empowerment of Indonesian Civil Society," The Indonesian Quarterly, vol. 24 (1), 1996.

----, Demokrasi dan Civil Society, Jakarta: LP3ES, 1996.

Huntington, Samuel P., The Clash of Civilizations, Foreign Affairs, 72: 3, 1993.

Isre (ed.), Tabayun Gus Dur. Pribumisasi Islam Hak Minoritas Reformasi Kultural, Yogyakarta: LKiS, 1998.

Keane, John, "Despotism and Democracy: The Origins and Development of the Distinction Between Civil Society and the State 1750-1850," in John Keane (ed.), Civil Society and The State: New European Perspectives, New York: Verso, 1988.

Liddle, William, "The Islamic Turn in Indonesia: A Political Explanation," Journal of Asian Studies, vol. 55, (3), 1996.

Madjid, Nurcholish, "Suatu Saat ICMI Akan Diterima Semua Pihak," in Nasrullah A. Fauzi (ed.), ICMI: Antara Status Quo dan Demokratisasi, Bandung: Mizan, 1995.

----, "Prinsip Kemanusiaan dan Musyawarah dalam Politik Islam," in Nurcholish Madjid, Islam Agama Kemanusiaan: Membangun Tradisi dan 
Visi Baru Islam Indonesia, Jakarta: Paramadina, 1995.

----, "Dinamika Budaya Pesisir dan Pedalaman: Menumbuhkan Masyarakat Madani," in Abdullah Hafiz, et.al. (eds.), HMI dan KAHMI:Menyongsong Perubahan, Menghadapi Pergantian Zaman, Jakarta: Majelis Nasional KAHMI, 1997.

Mahasin, Aswab, "Konsolidasi Berlebihan bisa Mengkhawatirkan," in Nasrullah Ali-Fauzi (ed.), ICMI: Antara Status Quo dan Demokratisasi, Bandung: Mizan, 1995.

Marshall, T.H., Citizenship and Social Class and Other Essays, Cambridge: Cambridge University Press, 1950.

McVey, Ruth, "Faith as the Outsider: Islam in Indonesian Politics," in James P. Piscatori (ed.), Islam in the Political Process, Cambridge: Cambridge University Press, 1983.

Mun'im, D.Z., Abdul, “Distorsi Terhadap Masyarakat Sipil,” Kbittah, No. 1, November 1999.

Oxhorn, Philip, "From Controlled Inclusion to Reactionary Exclusion: The Struggle for Civil Society in Latin America," in John Hall (ed.), Civil Society: Theory, History and Comparison, Cambridge: Polity Press, 1995.

----, Organizing Civil Society: The Popular Sectors and the Struggle for Democracy in Chile, University Park: The Pennsylvania State University Press, 1995.

----, When Democracy Isn't All that Democratic: Social Exclusion and the Limits of the Public Sphere in Latin America, North South Agenda Paper 44. Coral Gables, Fla.: North South Center at the University of Miami, April 2001.

----, "Social Inequality, Civil Society and the Limits of Citizenship in Latin America," in Susan Eckstein and Timothy Wickham-Crawley (eds.), What Justice? Whose Justice? Fighting for Fairness in Latin America, Berkeley: University of California Press, 2003.

Price, Daniel E., Islamic Political Culture, Democracy and Human Rights: A Comparative Study, Westport, Connecticut: Praeger, 1999.

Rahardjo, Dawam, "Visi dan Misi Kehadiran ICMI: Sebuah Pengantar," in Nasrullah Ali-Fauzi (ed.), ICMI: Antara Status Quo dan Demokratisasi, 
The Contested Representation of Muslim Civil Society in Indonesia

Bandung: Mizan, 1995.

----, "Mereka Tidak Konsisten Memandang ICMI," in Nasrullah AliFauzi (ed.), ICMI: Antara Status Quo dan Demokratisasi, Bandung: Mizan, 1995.

----, "ICMI, Masyarakat Madani, dan Masa Depan Politik Indonesia: Sebuah Catatan Akhir," in Nasrullah Ali-Fauzi (ed.), ICMI: Antara Status Quo dan Demokratisasi, Bandung: Mizan, 1995.

Rais, Amien, "ICMI Harus Menyentuh Akar Rumput Umat," in Nasrullah Ali-Fauzi (ed.), ICMI: Antara Status Quo dan Demokratisasi, Bandung: Mizan, 1995.

Ramage, Douglas, "Democratization, Religious Tolerance and Pancasila: The Political Thought of Abdurrahman Wahid," in Greg Barton and Greg Fealy (eds.), Nahdlatul Ulama, Traditional Islam and Modernity in Indonesia, Clayton: Monash Asia Institute, 1996.

----, Politics in Indonesia: Democracy, Islam and the Ideology of Tolerance, London and New York: Routledge, 1995.

Rumadi, "Civil Society dan NU Pasca Gus Dur," Kompas, 5 November 1999.

Sanit, Arbi, "Yang Kecil Tidak Bisa Lama Menunggu," in Nasrullah AliFauzi (ed.), ICMI: Antara Status Quo dan Demokratisasi, Bandung: Mizan, 1995.

Sasono, Adi, "Jangan Terjebak Pemikiran Konfrontatif," in Nasrullah A. Fauzi (ed.), ICMI: Antara Status Quo dan Demokratisasi, Bandung: Mizan, 1995.

Taylor, Charles, "Modes of Civil Society," Public Culture, vol. 3, (1) Fall 1990.

Wahid, Abdurrahman, "ICMI Memang Sektarian, Kok," in Lukman Hakiem, Tamsil Linrung, Mahmud F. Rakasima (eds.), Mereka Bicara tentang ICMI: Sorotan 5 Tabun Perjalanan ICMI, Jakarta: Amanah Putra Nusantara, 1995.

Wahid, Abdurrahman, "Islam dan Civil Society: Pengalaman Indonesia," Halqah, No. 6, 1998.

Walzer, Michael, "Rescuing Civil Society," Dissent (Winter), 1999.

Wertheim, W.F., "Indonesian Moslems under Sukarno and Suharto: 
Arskal Salim

Majority with Minority Mentality", Studies on Indonesian Islam, Occasional Paperno. 19. Centre for Southeast Asian Studies, University of North Queensland Australia, 1986. 